\title{
Morphology and growth pattern of Nike fish (amphidromous goby larvae) in Gorontalo Waters, Indonesia
}

\author{
Nuralim Pasisingi ${ }^{1 *}$, Abdul Hafidz Olii ${ }^{1}$, Sitty Ainsyah Habibie ${ }^{1}$ \\ ${ }^{1}$ Faculty of Fisheries and Marine Science, Gorontalo State University, Indonesia. \\ *Corresponding author: nuralim@ung.ac.id
}

\section{ARTICLE INFO}

\section{Keywords:}

Allometric; Amphidromous; Goby; Growth Pattern;

Lenght-Weight Relationship

\section{How to cite:}

Pasisingi, N., Olii, A. H., \&

Habibie, S. A. (2020).

Morphology and growth

pattern of Nike fish

(amphidromous goby

larvae) in Gorontalo Waters,

Indonesia. Tomini Journal of

Aquatic Science, 1(1), 1-7

\begin{abstract}
Nike is a terminology used by Gorontalo local community to name schooling of minuscule amphidromous goby fish that has a limited appearance in Gorontalo waters. Understanding the biological performance of Nike fish is vital for implementing management and conservation strategy. This study aims to analyze daily recruitment and to determine growth patterns of Nike fish population in nature. Sampling was conducted in the Gorontalo waters during March, April, and May 2018 using a fish net with a mesh size of 0.5 inches. The duration of the appearance of Nike schooling in waters varies every month. The number of fish samples collected each month in this study ranged from 150 to 300 individuals. This study reveals that body color diversity and morphology of Nike fish strongly alleged to depend on where and how long they appear in the waters. Based on the daily recruitment pattern, Nike fish population distributed in Gorontalo waters is predicted to consist of individuals from multi-generation with an average length range of $1.848-2.805 \mathrm{~cm}$. During the sampling time, a positive allometric growth pattern indicated by the population.
\end{abstract}

\section{INTRODUCTION}

Gorontalo waters, Indonesia as part of Tomini Bay, is considered to have abundant fish resources due to according to Kadim et al. (2019), the morphology of Gorontalo Bay, which is semi-closed causes the status of water fertility to be highly determined by the input of inorganic or organic materials originating from the mainland. Moreover, Wagiyo et al. (2019) stated that, ecologically, Tomini Bay functions as a spawning, maintaining, and capturing the type of fisheries resources. The use of large amounts of fish resources as a protein source is a community need that will continue steadily. Nike fish becomes the icon of Gorontalo region due to its typical taste and has relatively high market demand.

Nike is a terminology used by the local community to name a group of minuscule fish that has a limited appearance in Waters of Gorontalo. Pasisingi and Abdullah (2018) stated that Nike is an amphidromous group that migrates from sea to river with the duration of its emergence in the waters of Gorontalo Bay, occurring for 3 to 9 days in the final moon phase towards the new moon. Additionally, Nike, that once alleged as endemic species in Gorontalo waters is the larvae of the group of fish belonging to the Gobiidae and Eleotridae family. Olii et al. (2017) stated that 
Nike is a group of Awaous sp. Recent studies have revealed that Nike fish are composed of species Sicyopterus longifilis (Olii et al., 2019), S. pugnans, S. cynocephalus, Belobranchus segura, and Bunaka gyrinoides (Sahami et al., 2019).

The previous research of Nike fish in Gorontalo Bay focuses on the speciation aspect. On the other hand, fishing activities and demand for Nike fish coincide. Therefore, information about the daily recruitment and growth patterns of Nike fish population in Gorontalo Bay is necessary as primary data supporting the sustainable management of Nike resources.

\section{MATERIAL AND METHODS}

Study site. Sampling was carried out in Gorontalo waters (Figure 1) during March, April, and May 2018 following the period in which the fish appeared in the waters. Fish sampling was conducted by submerging the net with mesh size 0.5 inches at a depth of 1-5 meters for about 30 minutes and was hauled immediately after the fish were trapped. The range of Nike fish samples obtained each month ranged from 150-300 individuals. Fish samples were preserved using ice cubes for laboratory analysis purposes. The total length of the samples was measured by calipers with a precision of $0.001 \mathrm{~cm}$, while a digital scale weighed the fish body samples with an accuracy of 0.01 grams.

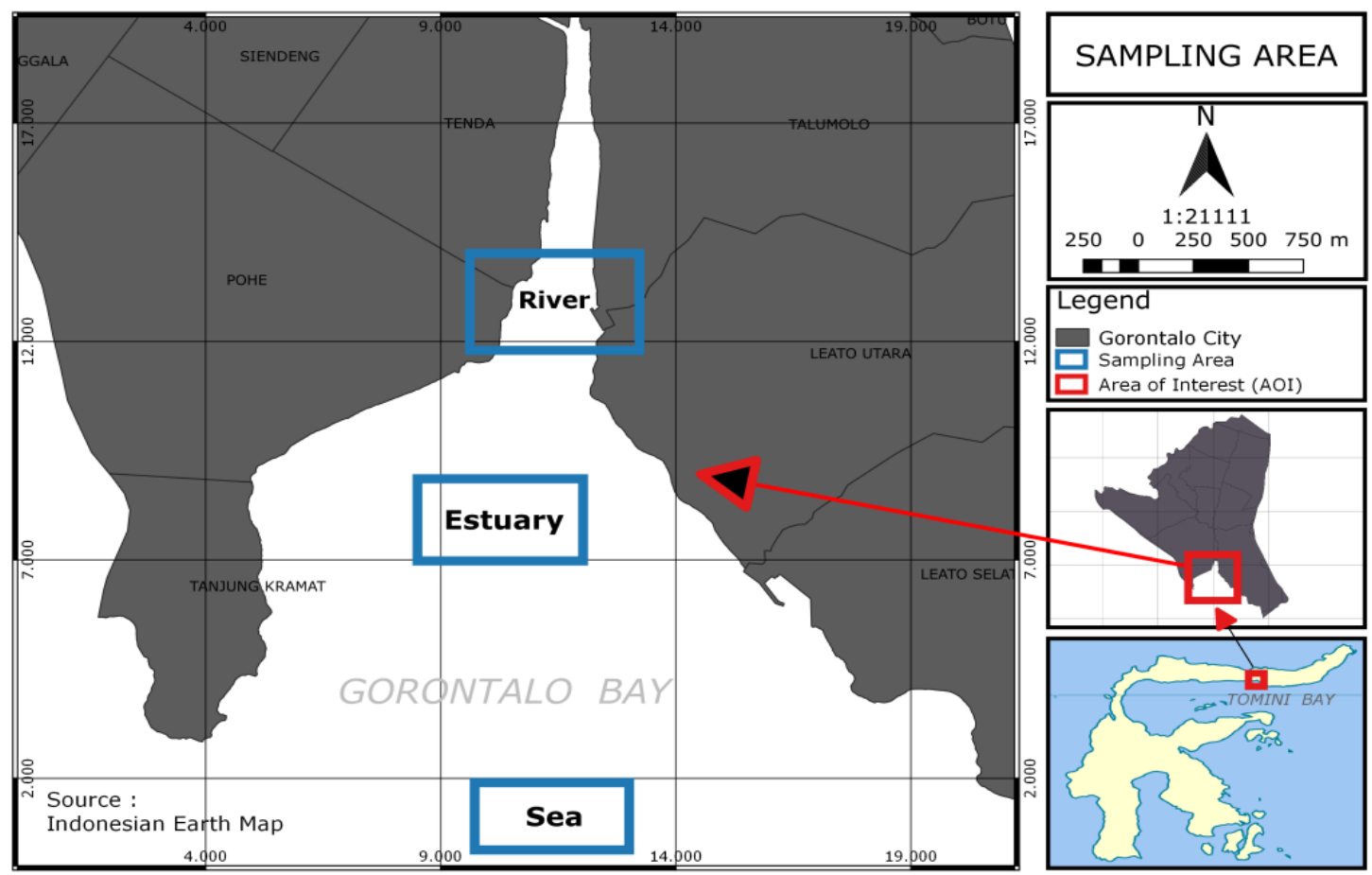

Figure 1. Sampling area of Nike fish

Data analysis. Nike fish morphology data were analyzed descriptively. Visualization of data on the total length composition of Nike fish population to estimate the daily recruitment was presented through bar charts. Whereas the relationship of weight length and t-test data were analyzed by Simple Linear Regression using Microsoft Excel Software then visualized to scatter diagrams.

\section{RESULTS AND DISCUSSION}

Amphidromous goby fishes live and lay eggs in the freshwater. Upon hatching, larvae are swept downstream to the ocean and develop and migrate upstream to adult habitats. Moving between habitats introduces unique challenges that migrating organisms must overcome to reach their 
intended destinations (Diamond, 2019). Amphidromous is a form of migratory life history where the reproduction occurs in freshwater and spreading of post-hatch larvae in the marine environment; then the small-bodied young juveniles return to freshwater environments for growth to adulthood (Franklin \& Gee, 2019). The dynamics of Gorontalo Bay waters as Nike fish habitat are predicted to determine fish morphology and growth in nature.

Nike fish morphology. The larval stage is a subtle phase for identification purposes. Although several goby species in Indonesian waters have been identified (Keith et al., 2011; Keith et al., 2012; Keith et al., 2014; Keith et al., 2015), their simultaneous and clustered emergence in waters needs a circumspection applying single species fisheries management. Development in the early life stages of Nike fish experiences alteration of salinity and predation threat. Augspurger and Closs (2019) stated that early life history is widely recognized as the stage of fish life history where mortality is the highest. Incorrect adaptation of early life-history characteristics to environmental conditions will result in high larval mortality and, therefore, recruitment failure. The samples from this research show that the fish has a morphology variation (Figure 2).

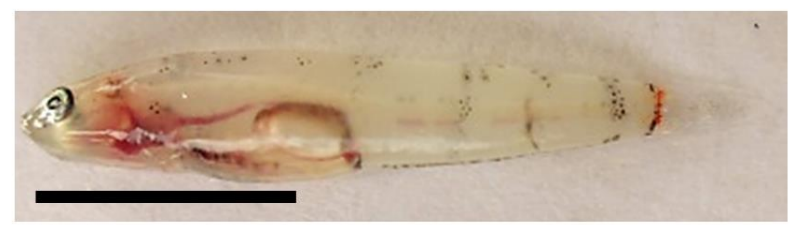

(a)

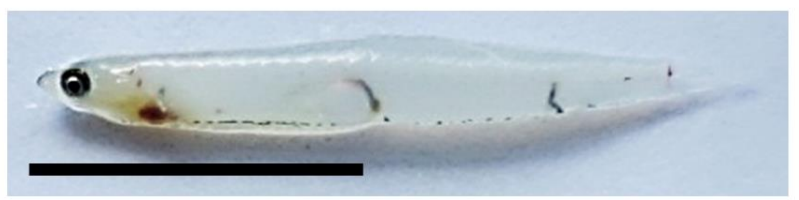

(c)

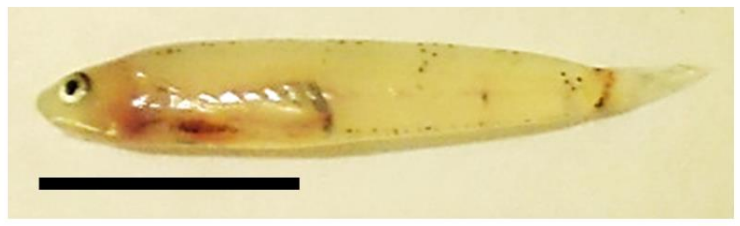

(b)

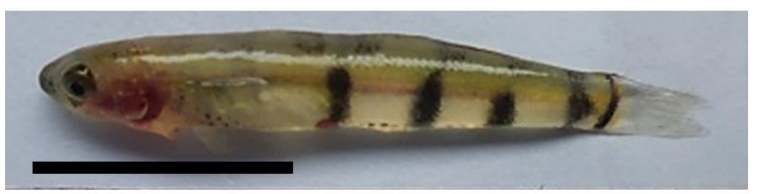

(d)

Figure 2. Morphology of Nike fish from Gorontalo Waters found in the area of

(a) Sea 1 (b) Sea 2 (c) Estuary (d) Bone River (scale bar = $1 \mathrm{~cm}$ )

Morphologically, the fish on the first day of its occurrence in sea waters have a transparent body, smooth and thin pectoral and dorsal fins, black eyespot adjoining by white portion. The operculum part seems to like outside the body as there are reduction yolk eggs (Figure $2 a$ ). On the following day, fish also appear in the area of seawater. Its body color looks compact. However, it performs from the outer that the inside of the body is still straightforward. No bumps were found in the abdomen, and all fins are in the developing phase (Figure $2 b$ ). The body of the Nike found in the estuary area is rounded white, and streamline in shape, and the black eye protrudes outward with no white area in its around (Figure 2c). Nike appearing in the river, at the end of their presence, has a dark color, and the pectoral, dorsal, and anal fins develop almost entirely. The melanophore ring-shaped appears along the body (Figure 2d).

In general, the variations of Nike color and morphology are influenced by where they appear and how long they are in the waters. Transparent body occurs that the fish are in pre larvae then transforms into a compact body that indicates that the fish develop to its next life stage, postlarvae. In other words, salinity, as well as life phases, simultaneously determine and support the existence of goby larvae in nature. Murase and Iguchi (2019) reported that variations in the diadromous fish life cycle could be explained by differences in food availability between marine and freshwater habitats because migration is often interpreted as a mechanism for exploiting food resources. A life-history stage of organisms that can disperse through seawater requires a physiologically challenging migration across a salinity boundary (Kaemingk et al., 2019).

This study considers that differentiation of species composer Nike schooling is predicted to be another factor that influences the ability to adapt to the dynamics of environmental change. 
Downie et al. (2020) found that significant morphological and physiological modifications characterize the larval phase of marine teleost fishes. Larval fish performances are highly variable among species and are driven by temperature. Therefore, comprehensive studies of Nike species are needed to show the form of the alteration. Local adaptation of marine and diadromous species is estimated to be a product of larval dispersal, settlement mortality, and differential reproductive success, particularly in heterogeneous post-settlement habitats (Moody et al., 2019).

Daily recruitment pattern of Nike fish. Generally, changes in the length of the Nike schooling length are observed per day during sampling time (Figure 3). The average length of Nike fish found in this study ranged from $1.848 \mathrm{~cm}$ to $2.805 \mathrm{~cm}$.

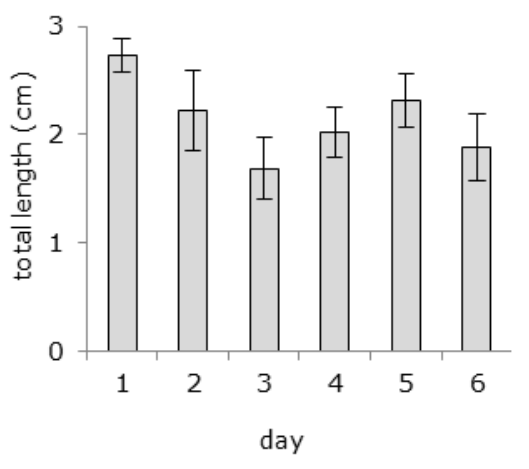

(a)

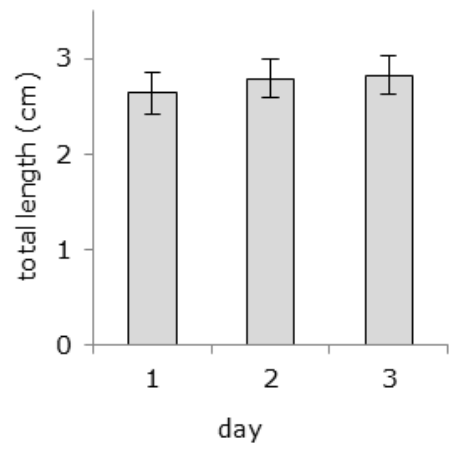

(b)

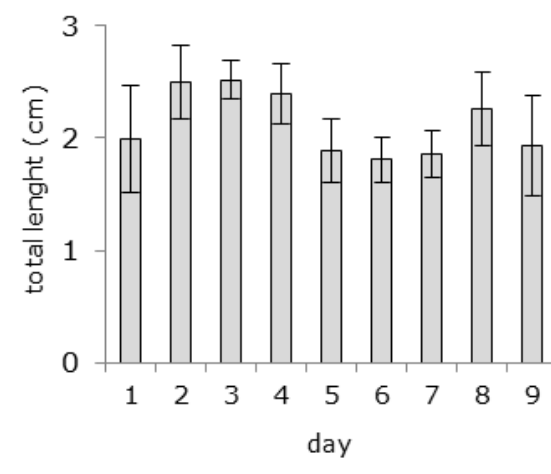

(c)

Figure 3. Length composition of Nike fish per day of the appearance during (a) March 2018; (b) April 2018; (c) May 2018 in Gorontalo waters

The distribution of Nike lengths during March and May shows that the length does not necessarily go up with time. Therefore, it is predicted that Nike fish found in these months is from individuals with different life phases. In April, Nike fish only appears in the waters for three days and shows a growth in length as the days increase. The pattern indicates that the individuals composing the fish population have a similar life phase. Nevertheless, the existing observational data is not sufficient to determine the cohort population and the seasonal pattern of Nike recruitment in nature. Bell et al. (1995) analyzed that both size and age of recruits of diadromous gobies, Sicydium punctatum and Sicydium antillarum in Dominica, West Indies vary seasonally, but the relationship of size to age is complicated. Although positively related within lunar-monthly recruiting cohorts, the overall relationship of size and age was poor because seasonal variation in size is out of phase with age. Jarvis et al. (2018) reported the results of a series of observational and experimental studies on bluegill bully (Gobiomorphus hubbsi). The study revealed that spawning primarily occurs in the lower reaches of the river, and larvae from different nests exhibited marked differences in, and trade-offs between larval characteristics at hatch, potentially affecting larval success. Therefore, there are two likelihoods of the daily recruitment of Nike schooling in nature. Firstly, Nike fish brooders spawn more than once a month. Secondly, the individual compilers Nike fish in this study are from different parents with dissimilarity gonad maturity level.

The growth pattern of Nike fish population. Growth is a complex biological process that is led by fish individually or in populations. Length measurements and sample weights found per day were averaged and analyzed through length-weight relationships (LWR) as a required method providing how the habitat where the fish live influences the biological conditions. The equation took the relations of various body length and mass: $W=a \times L^{b}$, where $W$ is the total body weight $(\mathrm{g})$, $\mathrm{L}$ the total length $(\mathrm{cm})$, while $a$ and $b$ are the regression parametric quantity. Based on the linear equation: $\ln (W)=\ln (a)+b \ln (L)$, the analysis of the parametric quantities of $a$ and $b$ of the LWR were calculated. Also, statistical significance levels of $R^{2}$ (coefficient of determination) were estimated by the $95 \%$ confidence intervals of a and b. Based on the t-test, Nike growth performs positive allometric growth (Figure 4). 


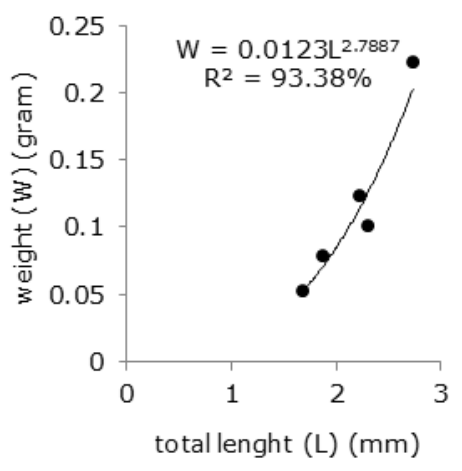

(a)

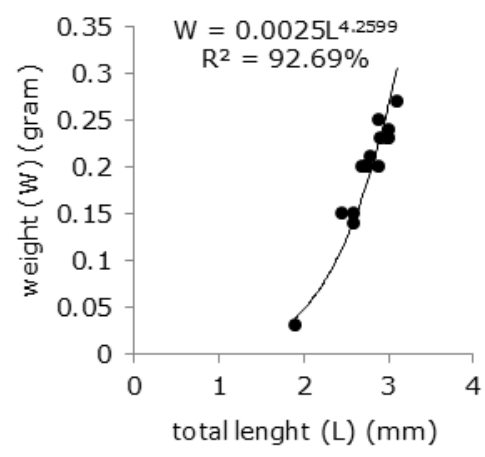

(b)

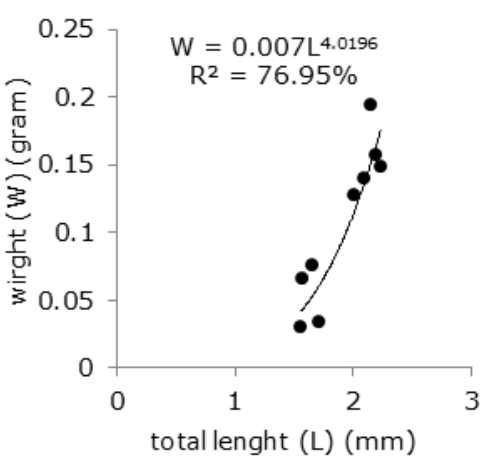

(c)

Figure 4. Length-Weight Relationship of Nike fish in Gorontalo waters during (a) March; (b) April; and (c) May 2018 in Gorontalo waters.

A positive allometric growth $(\mathrm{b}>3$ ) of Nike schooling in this survey illustrates that weight growth is more dominant than length increase. Although the study of survival rate due to the threat of capture cannot be explained through this growth pattern, b > 3 indicates that the waters of Gorontalo waters support the growth of Nike fish populations. Riedel et al. (2007) described that positive allometric growth implies the fish becomes relatively stouter or deeperbodied as it increases in length and is indicated by $a b>3$. Several studies reported the influences of water salinity and temperature on fish larval development and growth. Simulations through the model to assess the effects of climatic changes in the fish population by Souza et al. (2018) indicated that the common goby population is sensitive to both temperature and salinity changes. Overall, scenarios of more than $3^{\circ} \mathrm{C}$ increase caused significant population decreases. Similarly, increased salinities led to a population shrinkage, whereas scenarios of salinity decrease generated a different variation on the population. Chalant et al. (2019) supported the hypothesis stating that migration between ocean and freshwater occurs by choosing the biome that optimizes pre-reproductive growth and is one more example of the importance of primary productivity in shaping large-scale community patterns. Teichert et al. (2012) stated that temperature, food availability, and seasonal conditions affect survival and amphidromous larval growth. Jarvis et al. (2018) reported that larvae exhibited markedly higher survival rates when reared at intermediate salinities compared to freshwater or seawater, suggesting estuaries may play an essential role as nursery grounds for bluegill bully and other amphidromous fish. Therefore, a comprehensive study of the environmental conditions in Gorontalo waters is needed to support the results of this study. This study adds on to the general understanding of the biological performances in Nike schooling that will help implement strategies to Gorontalo waters management.

\section{CONCLUSION}

The daily recruitment pattern of Nike fish indicates that the fish population in Gorontalo waters is estimated to consist of multi-generation individuals. Additionally, Nike fish population has a positive allometric growth pattern during March, April, and May 2018.

\section{ACKNOWLEDGMENTS}

This research was funded by the Directorate of Research and Community Service, Ministry of Research, Technology, and Higher Education, Indonesia Republic. I would like to thank Ismet Panu, Thomas Tammu, Rizalul Fikrih, Nurul Hasanah, Dewi Juliyanti Hasiru, and Andri Amai for their technical help during this research. 


\section{REFERENCES}

Augspurger, J. M., \& Closs, G. P. (2019). Early life-history adaptation influences conservation approaches for facultatively amphidromous fish. Aquatic Conservation: Marine and Freshwater Ecosystems, 29(9), 1403-1408. https://doi.org/10.1002/aqc.3077

Bell, K. N., Brown, J. A., \& Pepin, P. (1995). Seasonal, inverse cycling of length-and age-atrecruitment in the diadromous gobies Sicydium punctatum and Sicydium antillarum in Dominica, West Indies. Canadian Journal of Fisheries and Aquatic Sciences, 52(7), 15351545. https://doi.org/10.1139/f95-147

Chalant, A., Jézéquel, C., Keith, P., \& Hugueny, B. (2019). The global geography of fish diadromy modes. Global Ecology and Biogeography 00, 1-11. https://doi.org/10.1111/geb.12931

Diamond, K. M. (2019). Functional Morphology and Environmental Impacts on MigrationRelevant Performance Measures in Amphidromous Goby Fishes (Doctoral Dissertation, Clemson University, South Carolina). Retrieved from https://tigerprints.clemson.edu/all_dissertations/2492

Downie, A. T., Illing, B., Faria, A. M., \& Rummer. (2020). Swimming performance of marine fish larvae: review of a universal trait under ecological and environmental pressure. Reviews in Fish Biology and Fisheries, 30, 93-108. https://doi.org/10.1007/s11160-019-09592-w

Franklin, P., \& Gee, E. (2019). Living in an amphidromous world: perspectives on the management of fish passage from an island nation. Aquatic Conservation: Marine and Freshwater Ecosystems, 29(9), 1424-1437. https://doi.org/10.1002/aqc.3049

Jarvis, M. G., Harland, H. A., Warburton, M. L., \& Closs, G. P. (2018). The spawning and early life-history of a New Zealand endemic amphidromous eleotrid, bluegill bully (Gobiomorphus hubbsi). New Zealand Journal of Marine and Freshwater Research, 52(1), 55-68. https://doi.org/10.1080/00288330.2017.1330760

Kadim, M. K., Pasisingi, N., \& Arsyad, S. (2019). Horizontal distribution of chlorophyll-a in the Gorontalo Bay. Nature Environment \& Pollution Technology, 18(4), 1381-1385. http://www.neptjournal.com/upload-images/NL-72-37-(35)D-928

Kaemingk, M. A., Swearer, S. E., Bury, S. J., \& Shima, J. S. (2019). Landscape edges shape dispersal and population structure of a migratory fish. Oecologia, 190(3), 579-588. https://doi.org/10.1007/s00442-019-04440-x

Keith, P., Allen, G., Lord, C., \& Hadiaty, R. K. (2011). Five new species of Sicyopterus (Gobioidei: Sicydiinae) from Papua New Guinea and Papua. Cybium, 35(4), 299-318. https://doi.org/10.26028/cybium/2011-354-004

Keith, P., Hadiaty, R. K., \& Lord, C. (2012). A new species of Belobranchus (Teleostei: Gobioidei: Eleotridae) from Indonesia. Cybium, 36(3), 479-484. https://doi.org/10.26028/cybium/2012-363-007

Keith, P., Hadiaty, R. K., Hubert, N., Busson, F., Lord, C., (2014). Three new species of Lentipes from Indonesia (Teleostei: Gobiidae). Cybium, 38(2), 133-146. https://doi.org/10.26028/cybium/2014-382-004

Keith, P., Lord, C., Busson, F., Sauri, S., Hubert, N., \& Hadiaty, R. K. (2015). A new species of Sicyopterus (Gobiidae) from Indonesia. Cybium, 39(4), 243-248. https://doi.org/10.26028/cybium/2015-394-001

Moody, K. N., Wren, J. L., Kobayashi, D. R., Blum, M. J., Ptacek, M. B., Blob, R. W., \& Childress, M. J. (2019). Evidence of local adaptation in a waterfall-climbing Hawaiian goby fish derived from coupled biophysical modeling of larval dispersal and post-settlement selection. BMC Evolutionary Biology, 19(1), 88. https://doi.org/10.1186/s12862-0191413-4

Murase, I., \& Iguchi, K. I. (2019). Facultative amphidromy involving estuaries in an annual amphidromous fish from a subtropical marginal range. Journal of Fish Biology, 95(6), 1391-1398. https://doi.org/10.1111/jfb.14147

Olii, A. H., Sahami, F. M., Hamzah, S. N., \& Pasisingi, N. (2017). Preliminary findings on distribution pattern of larvae of nike fish (Awaous sp.) in the estuary of Bone River, Gorontalo Province, Indonesia. AACL Bioflux, 10, 1110-1118. http://www.bioflux.com.ro/docs/2017.1110-1118

Olii, A. H., Sahami, F. M., Hamzah, S. N., \& Pasisingi, N. (2019). Molecular approach to identify gobioid fishes, "Nike" and "Hundala" (local name), 
from Gorontalo Waters, Indonesia. Online Journal of Biological Sciences, 19(1), 51-56. https://doi.org/10.3844/ojbsci.2019.51.56

Pasisingi, N., \& Abdullah, S. (2018). Pattern of nike fish (Gobiidae) occurrence in the Gorontalo Bay, Indonesia [Indonesian]. Depik, Jurnal Ilmu-Ilmu Perairan, Pesisir dan Perikanan, 7(2), 111-118. https://doi.org/10.13170/depik.7.2.11442

Riedel, R., Caskey, L. M., \& Hurlbert, S. H. (2007). Length-weight relations and growth rates of dominant fishes of the Salton Sea: implications for predation by fish-eating birds. Lake and Reservoir Management, 23(5), 528-535. https://doi.org/10.1080/07438140709354036

Sahami, F. M., Rene, K. C., Olii, A. H., \& Pratasik, S. B. (2019). What species make up the Nike fish assemblages at the macrotidal estuary in Gorontalo Bay, Indonesia?. F1000Research, 8(1654), 1-9. https://doi.org/10.12688/f1000research.19501.1

Souza, A. T., Ilarri, M. I., Timóteo, S., \& Marques. (2018). Assessing the effects of temperature and salinity oscillations on a key mesopredator fish from European coastal systems. Science of the Total Environment, 640-641, 1332-1345. https://doi.org/10.1016/j.scitotenv.2018.05.348

Teichert, N., Richarson, M., Valade, P., \& Gaudin, P. (2012). Reproduction and marine life history of an endemic amphidromous gobiid fish of Reunion Island. Aquatic Biology, 15(3), 225236. https://doi.org/10.3354/ab00420

Wagiyo, K., Priatna, A., \& Herlisman, H. (2019). Abundance, composition and distribution of fish larvae in the Seram Sea, Maluku Sea and Tomini Bay (WPP 715) [Indonesian]. BAWAL Widya Riset Perikanan Tangkap, 11(1), 117. http://dx.doi.org/10.15578/bawal.11.1.2019.1-17 